\title{
PATHOANATOMICAL FINDINGS OF A GREEN TURTLE (Chelonia mydas) VICTIM OF COLLISION WITH A MOTORBOAT
}

\author{
Radan Elvis Matias de OLIVEIRA ${ }^{1,2,3 *}$, Fernanda Loffler Niemeyer ATTADEMO ${ }^{2,3}$, \\ Augusto Carlos da Bôaviagem FREIRE ${ }^{2,3}$, Juliana Maia de Lorena PIRES ${ }^{2,3}$, Daniel \\ Solon Dias de FARIAS ${ }^{2,3,4}$, Aline da Costa BOMFIM ${ }^{2,3,4}$, Rysónely Maclay de \\ OLIVEIRA ${ }^{2,3,6}$, Simone Almeida GAVILAN ${ }^{2,3,5}$, Flávio José de Lima SILVA 2,3,4,5, \\ Moacir Franco de OLIVEIRA ${ }^{1}$
}

\begin{abstract}
${ }^{1}$ Postgraduate Program in Animal Science (PPGCA), Federal Rural University of the Semi-Arido (UFERSA), Mossoró, Rio Grande do Norte, Brazil; ${ }^{2}$ Costa Branca Cetaceans Project, University of the State of Rio Grande do Norte (PCCB-UERN), Mossoró, Rio Grande do Norte, Brazil; ${ }^{3}$ Center for Environmental Studies and Monitoring (CEMAM), Areia Branca, Rio Grande do Norte, Brazil; ${ }^{4}$ Doctoral Program in Development and Environment (PRODEMA), Federal University of Rio Grande do Norte (UFRN), Natal, Rio Grande do Norte, Brazil; ${ }^{5}$ Postgraduate Program in Structural and Functional Biology, Federal University of Rio Grande do Norte (UFRN), Natal, Rio Grande do Norte, Brazil; ${ }^{6}$ Postgraduate Program in Natural Sciences, University of the State of Rio Grande do Norte (UERN), Mossoró, Rio Grande do Norte, Brazil
\end{abstract}

(Received 18 August, Accepted 18 November 2021)

In this paper we report the trauma suffered by a green turtle (Chelonia mydas), caused by a collision with a motorboat, and describe the case ante and post-mortem. An adult female green turtle was rescued alive on December 2, 2016 at Ponta Negra beach, municipality of Natal, Rio Grande do Norte, Brazil. The rescued animal was sent to the Marine Fauna Rehabilitation Center (PCCB-UERN), municipality of Areia Branca (RN), in Brazil. Physical examination revealed an excellent body score, noisy breathing, moderate dehydration, absence of hind limb and cloacal reflexes when stimulated by pressure, and two traumatic injuries characteristic of a collision with a motorboat. After three days of supportive treatment, the animal died and was immediately sent for necropsy. The animal had a complete fracture of the vertebral bodies (dorsal elements D9 and D10) and spinal cord section. The entire gastrointestinal tract had food content, in addition to sharp injuries in the colon caused by the bone fragments of the fractured carapace. The lungs were congested, hemorrhagic with frothy and bloody secretion, and interstitial bronchiole fibrosis. There was also present some fibrin and a large number of leukocyte cells, consisting mainly of macrophages. The liver was enlarged, with rounded edges and thickening of the capsule, multifocal areas of hepatocellular necrosis, and dissociation of the hepatocyte cords. The collision resulted in the exposure of the coelomic cavity and spinal cord, causing the animal intense pain, paralysis of the hind limbs and cloaca, septicemia, and consequently, death.

Keywords: Cheloniidae, propeller, Testudines, trauma

*Corresponding author: e-mail: radan_elvis@hotmail.com 


\section{INTRODUCTION}

The green turtle (Chelonia mydas) is in the "endangered" category of extinction, according to the Red List of Endangered Species of the International Union for Conservation of Nature [1]. Human activities have been the leading cause of threat to the species through the effects of fishing activities [2] and motorboat collisions, which has led to increased mortality of these animals over the years [3].

Among the seven species of sea turtles worldwide, green turtles, followed by loggerhead turtles (Caretta caretta), comprise the majority of death records from collisions with motorboats [3]. The record of this cause of death, often underreported, is important for developing public policy measures for conservation, as the descriptions of these cases make it possible to identify which types of ships may be affecting these animals and what the impact on populations is [4].

The state of Rio Grande do Norte has been identified as an important area for the occurrence of the species C. mydas [5,6]. Thus, it is important to be aware of the effects of mechanized animal fishing activities in the state to assist researchers and public agencies in the adoption of mitigation measures. Herein, we report the trauma suffered by a green turtle (C. mydas) in Rio Grande do Norte, Brazil, due to a collision with a motorboat, describing the case ante and post-mortem.

\section{CASE PRESENTATION}

An adult female green turtle (C. mydas) was rescued alive on December 2, 2016 at Ponta Negra beach (552'50.6 'S 3510'18.2 “W), municipality of Natal, Rio Grande do Norte, Brazil (Figure 1). The stranding was registered by team members of the Cetaceans Project of Costa Branca, of the State University of Rio Grande do Norte (Projeto Cetáceos da Costa Branca, da Universidade do Estado do Rio Grande do Norte - PCCBUERN). The execution of activities with marine animals is authorized by SISBIOICMBio (License No. 13694-9) and the Ethics Committee on the Use of Animals of the Federal Rural University of the Semi-Arid (License No. 01/2019).

The animal was found stranded on the sand, prostrate, and having a complete fracture in the horny plates that make up the carapace, with exposure of the coelomic cavity and a fracture in the nasal bone. The turtle was rescued and sent to the Wildlife Rehabilitation Center of the PCCB, in the municipality of Areia Branca, Rio Grande do Norte (RN), Brazil. The animal's biometric data were: $121.0 \mathrm{~cm}$ of curvilinear carapace length (CCC), $108.5 \mathrm{~cm}$ of curvilinear carapace width (LCC), and $177.5 \mathrm{~kg}$ of body mass.

In a detailed clinical examination, some alterations were observed. Upon inspection, there was an excellent body score, noisy breathing, moderate dehydration, and two traumatic injuries, characteristic of a collision with a motorboat. The first injury corresponded to a fracture that extended transversally from the fifth corneal plate on 
the left side of the carapace to the middle of the fifth contralateral plate $(4.4 \mathrm{~cm}$ from the largest opening) with exposure of the coelomic cavity (Figures $2 \mathrm{~A}$ and $2 \mathrm{~B}$ ). The second injury was characterized by a comminuted fracture in the nasal bone $5.1 \mathrm{~cm}$ wide) with exposure of the left nasal sinus (Figure 2C), in addition to a sharp injury with lacerated edges in the left anterior fin (4.1 cm wide) (Figure 2D). The neurological examination was based on the methodology by Chrisman et al. [7] for sea turtles, where the absence of hind limb and cloaca reflexes was found when stimulated by pressure.

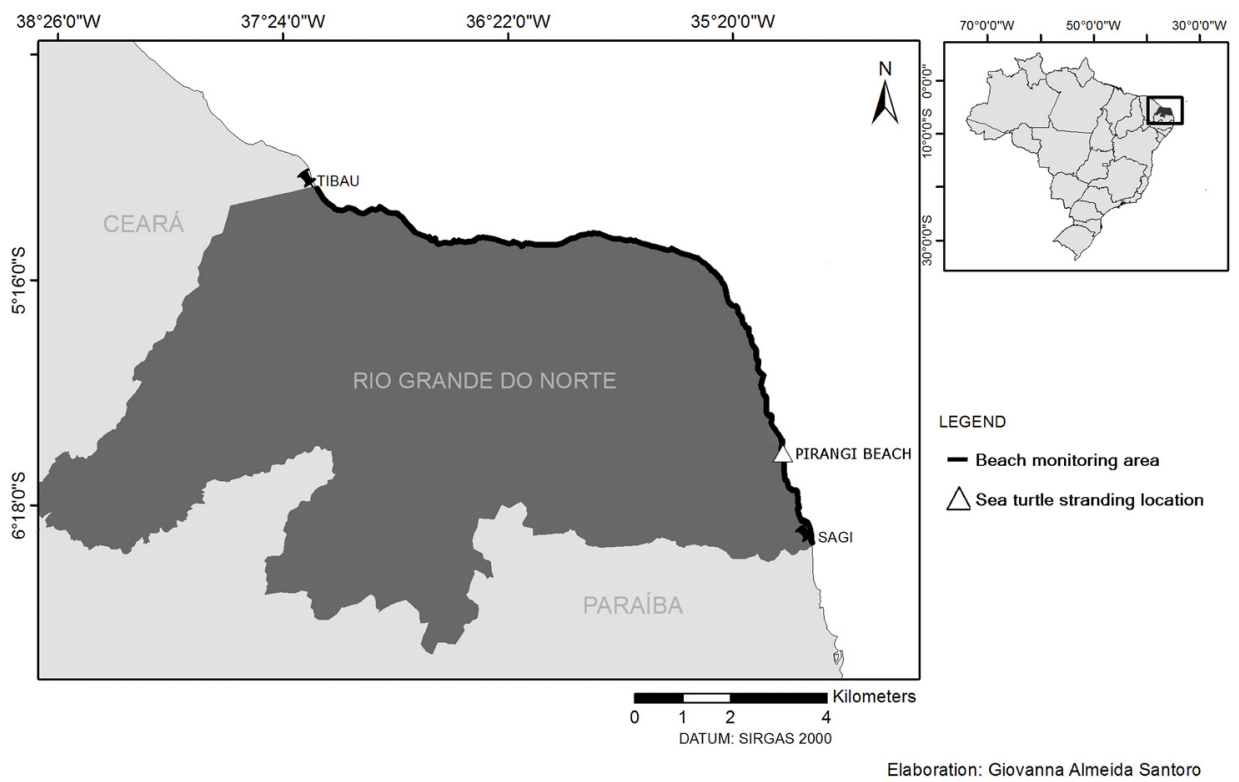

Figure 1. Area for monitoring the beaches for the Cetaceans Project in Costa Branca and site of the animal's stranding.

Emergency support treatment consisted of electrolyte replacement with $0.9 \%$ sodium chloride-based fluid therapy (KabiPac ${ }^{\circledR}$, dose: $20 \mathrm{ml} / \mathrm{kg} / \mathrm{EV} /$ speed: $30 \mathrm{drops} / \mathrm{min}$ ), diluted with vitamin B12 (Polivin B12 ${ }^{\circledR}$, dose: $0.3 \mathrm{ml} / \mathrm{kg} / \mathrm{EV}$ ), antitoxic (Mercepton ${ }^{\circledR}$, dose: $0.2 \mathrm{ml} / \mathrm{kg} / \mathrm{EV} / \mathrm{SID}$ ), and calcium gluconate (Calcifos ${ }^{\circledR}$, dose: $0.06 \mathrm{ml} / \mathrm{kg} / \mathrm{EV}$, SID), as well as antibiotic therapy with gentamicin sulfate (Gentamax ${ }^{\circledR}$, dose: $3 \mathrm{mg} /$ $\mathrm{kg} / \mathrm{IM}, \mathrm{SID}$ ), analgesia with tramadol hydrochloride (Tramal ${ }^{\mathbb{R}}$, dose: $4 \mathrm{mg} / \mathrm{kg} / \mathrm{SC}$, SID), meloxicam (Maxicam ${ }^{\circledR}$, dose: $\left.0.2 \mathrm{mg} / \mathrm{kg} / \mathrm{IM}, \mathrm{SID}\right)$, dipyrone (D-500 ${ }^{\circledR}$, dose: 25 $\mathrm{mg} / \mathrm{kg} / \mathrm{IM}$, TID) and dexamethasone (Dexaflan ${ }^{\circledR}$, dose: $\left.0.04 \mathrm{mg} / \mathrm{kg} / \mathrm{EV}, \mathrm{BID}\right)$. After three days of treatment, the animal died and was immediately sent for necropsy at the Marine Biota Monitoring Laboratory, at the State University of Rio Grande do Norte, in Mossoró (RN). 

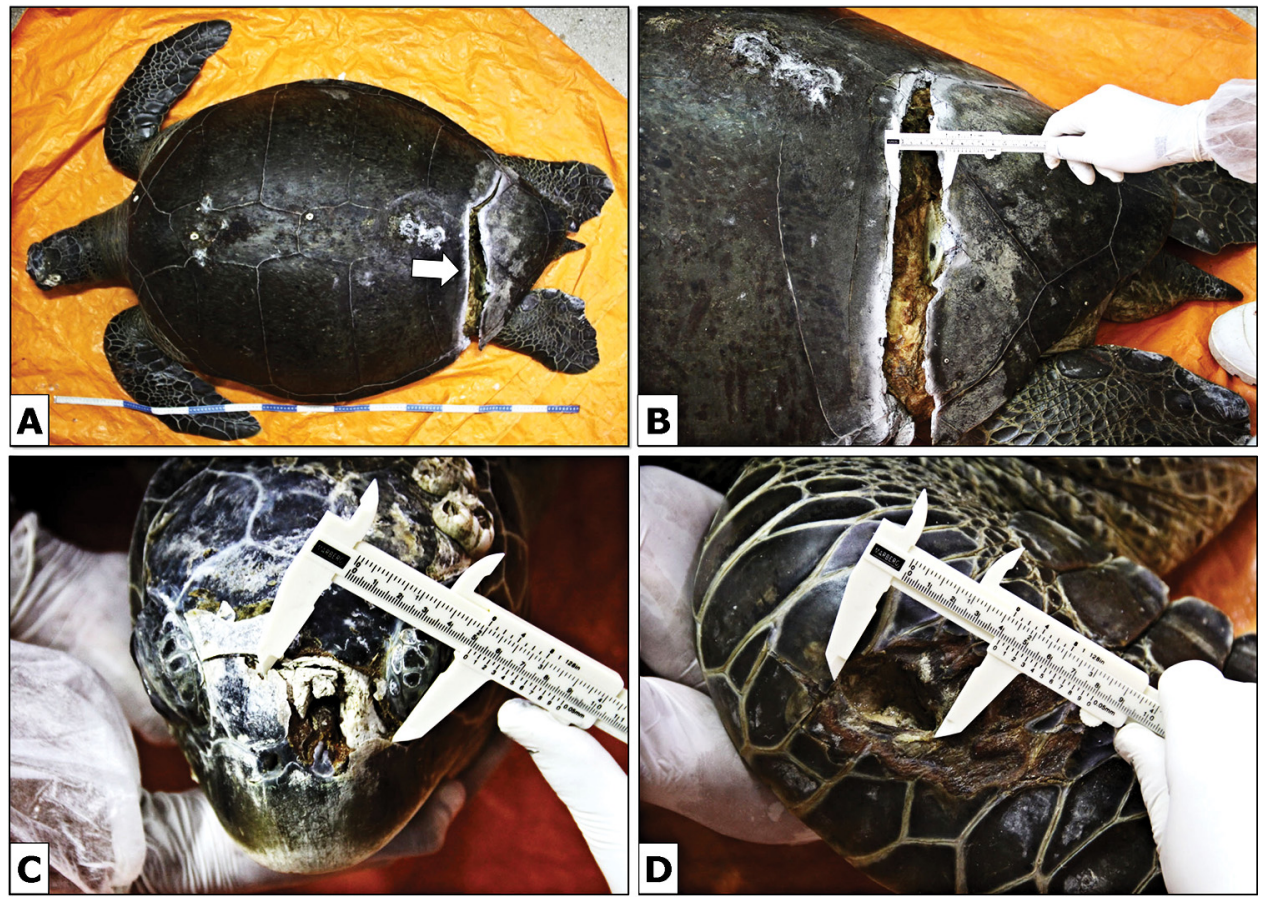

Figure 2. Traumatic injuries of a green turtle (Chelonia mydas) due to a collision with a motorboat. (A and B) a fracture is observed transversely from the fifth left corneal plate of the carapace to the middle of the fifth contralateral plate $(4.4 \mathrm{~cm}$ from the largest opening) with exposure of the coelomic cavity. (C) comminuted fracture in the nasal bone $(5.1 \mathrm{~cm}$ wide) with exposure of the left nasal sinus. (D) piercing-cutting injury on the left anterior fin with lacerated edges.

For macroscopic analysis, the Wyneken [8] methodology for sea turtles was used. Initially, the opening of the coelomic cavity was performed, surrounding the entire plastron, followed by its removal and analysis of the organs in situ. Then, all organs were removed for ex situ evaluation, and photographs of the evident macroscopic findings were taken. Tissue fragments were also collected and fixed in 10\% paraformaldehyde.

Liver and lung fragments, were collected and fixed in 10\% buffered formalin for histopathological examination. For histopathological analysis, the histological techniques recommended by Tolosa et al. [9] were used. Moreover, $5 \mu$ thick sections of paraffin blocks were made in a microtome (LEICA RM 2125 RT®), adhered to glass slides, and left in an oven at $60^{\circ} \mathrm{C}$ overnight for subsequent staining with hematoxylin and eosin (HE). The histological slides were analyzed under a light microscope (LEICA DM 500 HD) with a camera attached (LEICA ICC50W), and images were obtained using the LAS EZ Ink program.

The animal presented a complete fracture of the vertebral bodies (dorsal elements D9 and D10) and spinal cord section (Figure 3A). The entire gastrointestinal tract had food content, in addition to sharp lesions in the colon, caused by the bone fragments of the fractured carapace (Figure 3B). The lungs were congested and hemorrhagic with 
frothy and bloody secretion (Figure 3C). Histopathological examination of the lung showed interstitial fibrosis of the bronchioles, in addition to the presence of fibrin and a large number of leukocyte cells, consisting mainly of macrophages (Figure 3D). The liver was enlarged in size, with rounded edges and a thickened capsule (Figure 3E). Histopathological examination revealed multifocal areas of hepatocellular necrosis and dissociation of the hepatocyte cords (Figure 3F).

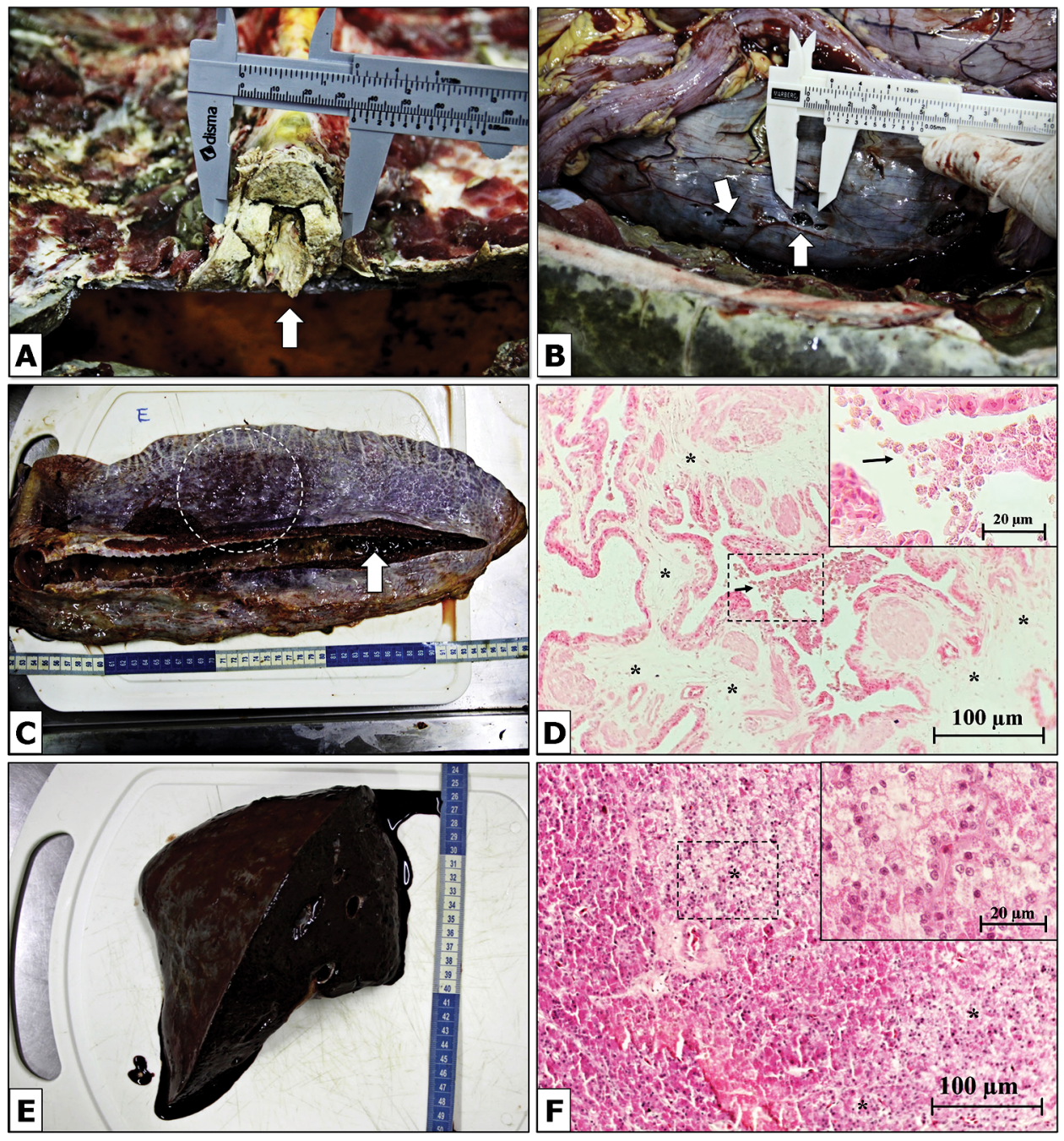

Figure 3. Anatomopathological and histopathological findings of a green turtle (Chelonia mydas) killed by collision with a motorboat. (A) complete fracture of the vertebral bodies (dorsal elements D9 and D10) and spinal cord section (arrow). (B) piercing-cutting lesions in the colon (arrows). (C) left lung congested, hemorrhagic (dashed circle), and with frothy and bloody secretion in the bronchus (arrow). (D) interstitial fibrosis of the bronchioles (asterisks), in addition to the presence of fibrin and a large number of leukocyte cells, consisting mainly of macrophages (arrow). (E) an enlarged liver with rounded edges and capsule thickening. (F) multifocal areas of hepatocellular necrosis (asterisks) and dissociation of the hepatocyte strands (highlighted figure of F). D and $\mathrm{F}=$ staining (HE). 


\section{DISCUSSION}

The increased number of motorboats worldwide explains the rise in mortality rates of marine animals due to being run over [10]. As sea turtles are lung-breathing, they often need to surface to breathe, leaving them vulnerable to collisions with motorboats. Another behavior that increases the chances of green turtles colliding with boats is that these animals feed in more coastal environments [11].

The cause of extensive and deep lesions on the shell of sea turtles may be due to them contacting the propellers, hulls, or keels of boats $[3,4]$. The type and severity of the injury in some situations may be related to the part of the boat that collided with the animal and be related to the boat speed at the time of the collision [4,12]. In this sense, the propellers produce multiple, linear, parallel, penetrating, and regularly spaced injuries at the same angle [4,13], while the hull or keel of the boat causes blunt wounds [14]. According to the evidence and severity of the injuries shown in this case report and considering the large size of the animal, we believe that the collision is related to the hull or keel of a boat, which was most likely going at high speed.

Hazel et al. [12], when carrying out an experimental study with green turtles to assess the escape behavior of these animals, revealed that the speed of boats directly influences the animals' escape. That is the proportion of turtles that fled to avoid collisions significantly decreased as the speed of boats increased. In this sense, there is the possibility that the animal reported here has been run over by a boat at high speed, for example, a speedboat, considering that this type of boat is authorized on the beach at the place of stranding [15].

According to Hazel and Gyuris [3], from 1990 to 2002, mortality records related to collisions with ships on the east coast of Queensland, in the United States, accounted for between $12 \%$ and $16 \%$ of the annual stranding records of sea turtles. Of the total records related to collisions with boats, the majority corresponded to green turtles $(76 \%)$, followed by loggerhead turtles (Caretta caretta; 14\%). Regarding age group, $72 \%$ of cases corresponded to adult turtles or sub-adults. Adult turtles have a higher reproductive value than juveniles, so the increased mortality of individuals in this age group should be given higher priority [16].

Sea turtles have an axial skeleton composed of a carapace, plastron bones, vertebrae, ribs, and rib derivatives [8]. In this case, the injury, probably due to a collision with a boat, produced fractures in the vertebral bodies (dorsal elements D9 and D10). Barten [17] states that fractures in this region can cause spinal cord injuries and severe and irreversible neurological signs. Fichi et al. [5] reinforce that the exposure of the coelomic cavity and injuries to the internal organs trigger serious bacterial infections, leading to the animal's death. Affected animals are usually found dead or in a very critical condition [18]. In this report, the bacterial entry point were the multiple fractures in the animal, particularly in the spinal cord section, which may have evolved into bacterial meningitis. The histopathological findings of the lungs, such as 
intrabronchiolar fibrin-leukocyte exudate and the cellular response, are consistent with a possible bacterial infection [19]. Consequently, another finding such as hepatocellular necrosis was evidenced and characteristic of septicemia, which is considered to be due to the trauma of the boat collision.

Aleksić-Kovačević et al. [20], in a study based on histopathological and microbiological examinations through biopsies of the pathoanatomical findings of the skin, plastron, carapace and skeletal system of 150 European pond turtles (Emys orbicularis), all taken from their natural habitats in lakes in Serbia, found that in the plastron, inflammatory and degenerative processes were frequently found, while osteopathies and mechanical injuries were the dominant findings. Microbiological examinations showed the presence of a variety of bacterial and fungal agents, primary pathogens or potential pollutants, which invaded the skin and carapace. These agents were present in the cloacal swab samples. Bacterial infections were diagnosed in $76.66 \%$ of the turtles, mainly those with skin and carapace necrosis, while mycoses were diagnosed in $33.33 \%$ of the animals. Therefore, these findings reinforce that lesions at the integument level will lead to possible infections by bacterial and fungal agents present in the natural environment of these animals. In our study, although we did not perform microbiological tests, we hypothesized that agents present in the marine environment were responsible for the infections and alterations observed in the necroscopic and histopathological examinations in the sea turtle.

According to the findings presented here, we assume that the green turtle suffered a collision with a motorboat. This resulted in the exposure of the coelomic cavity and spinal cord and caused intense pain, hind limb paralysis, and cloaca to the animal, in addition to septicemia and the animal's death. This report highlights the need to implement mitigation measures to reduce this type of impact on sea turtles, such as promoting conservation through environmental education tools, regulations, and inspections.

\section{Acknowledgments}

We thank the Coordination for the Improvement of Higher Education Personnel (CAPES, Financial Code 001) for the PhD scholarship granted to the Postgraduate Program in Animal Science (PPGCA-UFERSA), and the entire team of veterinarians and biologists of the Cetáceos da Costa Branca Project (PCCB-UERN/CEMAM) working in the Potiguar Bay Monitoring Program, who helped rescue the animal and perform its necropsy.

\section{Authors' contributions}

REMO, FLNA, DSDF, ACB, ACBF, SAG, FJLS, and MFO participated in interpretation of data and drafting of the manuscript. REMO, ACBF, JMLP, and RMO performed laboratory analyses (necropsy and histopathology). REMO, FLNA, FJLS, and MFO involved in conceptualization, methodology, interpretation, and critical revision of the manuscript. All authors read and approved the final manuscript. 


\section{Declaration of conflicting interests}

The authors declared no potential conflicts of interest with respect to the research, authorship, and/or publication of this article.

\section{REFERENCES}

1. IUCN: Chelonia mydas. In: The IUCN Red List of Threatened Species. [https://www. iucnredlist.org/species/4615/11037468]

2. Sales G, Giffoni BB, Barata PCR: Incidental catch of sea turtles by the Brazilian pelagic longline fishery. J Mar Biolog Assoc UK 2008, 88:853-864.

3. Hazel J, Gyuris E: Vessel-related mortality of sea turtles in Queensland, Australia. Wildl Res 2006, 33:149-154.

4. Work PA, Sapp AL, Scott DW, Dodd MG: Influence of small vessel operation and propulsion system on loggerhead sea turtle injuries. J Exp Mar Biol Ecol 2010, 393:168175.

5. Fichi G, Cardeti G, Cersini A, Mancusi C, Guarducci M, Di Guardo G, Terracciano G: Bacterial and viral pathogens detected in sea turtles stranded along the coast of Tuscany, Italy. Vet Microbiol 2016, 185:56-61.

6. Oliveira REM, Rossi S, Attademo FLN, Santoro TA, Revoredo RA, Farias DSD, Lima MA, Batista JS, Silva FJL, Gavilan SA, Oliveira MF: Colocolic intussusception associated with Octangium sp. (Digenea: Microscaphidiidae) in a green sea turtle (Chelonia mydas). J Aquatic Anim Health 2021, 32:17-23.

7. Chrisman CL, Walsh M, Meeks JC, Zurawka H, LaRock R, Herbst L, Schumacher J: Neurologic examination of sea turtles. J Am Vet Med Assoc 1997, 211:1043-1047.

8. Wyneken J: La Anatomía de las Tortugas Marinas. [The Anatomy of Sea Turtles]. Miami, Florida: U.S. Department of Commerce NOAA Technical Memorandum NMFSSEFSC-470; 2004, 172 p.

9. Tolosa EMC, Rodrigues CJ, Behmer AO, Neto AGF: Manual de técnicas para histologia normal e patológica. [Manual of techniques for normal and pathological histology]. 2nd ed. Barueri, SP: Manole; 2003, 331p.

10. Firestone J: Policy considerations and measures to reduce the likelihood of vessel collisions with great whales. Boston Coll Environ Aff Law Rev 2009, 36:389- 400.

11. Mcarthur S, Meyer J, Innis C: Anatomy and physiology. In: Mcarthur S, Wilkinson R, Meyer $\mathrm{J}$ (Eds.) Medicine and surgery of tortoises and turtles. Oxford, United Kingdom: Blackwell; 2004, $35-71$.

12. Hazel J, Lawler IR, Marsh H, Robson S: Vessel speed increases collision risk for the green turtle Chelonia mydas. Endang Species Res 2007, 3:105-113.

13. Freire ACB, Oliveira REM, Pires JML, Attademo FLN, Pereira AB, Melo LIS, Dantas MAM, Farias DSD, Bomfim AC, Bellini C, Gavilan SA, Silva FJL: Rehabilitation of a green sea turtle (Chelonia mydas) after collision with motorboat in the archipelago of Fernando de Noronha, Brazil. Braz J Case Rep 2021,1:116-124.

14. Martinez E, Stockin KA: Blunt Trauma Observed in a Common Dolphin Delphinus sp. Likely Caused by a Vessel Collision in the Hauraki Gulf, New Zealand. Pac Conserv Biol 2013, 19:19-27. 
15. Marinha do Brasil: Normas da autoridade marítima para amadores, embarcações de esporte e/ou recreio e para cadastramento e funcionamento das marinas, clubes e entidades desportivas náuticas- NORMAM-03/DPC [Maritime authority rules for amateurs, sports and/or recreational vessels and for registration and operation of marinas, clubs and nautical sports entities- NORMAM-03/DPC]. [https://www.marinha.mil.br/dpc/sites/www. marinha.mil.br.dpc/files/Port.7-2021-DPC_NORMAM-03\%20\%28Internet $\% 29$. pdf].

16. Heppel SS, Crowther LB, Menzel TR: Life table analysis of long-lived marine species with implications for conservation and management. Am Fish Soc Symp 1999, 23:137-148.

17. Barten SL: Shell demage. In: Mader DR (Ed.) Reptile medicine and surgery. Saint Louis, Missouri: Elservier Saunders; 2006, 893-899.

18. Franchini D, Cavaliere L, Valastro C, Carnevali F, Van Der Esch A, Lai O, Di Bello A: Management of severe head injury with brain exposure in three loggerhead sea turtles Caretta caretta. Dis Aquat Org 2016, 119:145-152.

19. Oliveira REM, Pires JML, Batista JS, Attademo FLN, Farias DSD, Freire ACB, Bomfim AC, Lima LRP, Oliveira RM, Gavilan SA, Silva FJL, Oliveira MF: Death of a loggerhead sea turtle (Caretta caretta) from ingestion of an eel (Myrichthys ocellatus). Vet Med-Czech 2020, 65:415-420.

20. Aleksic-Kovacevic S, Özvegy J, Krstić N, Rusvai M, Jakab C, Stanimirović Z, Becskei Z: Skin and skeletal system lesions of European pond turtles (Emys orbicularis) from natural habitats. Acta Vet Hung 2014, 62:180-193.

\title{
PATOANATOMSKI NALAZ KOD ZELENE KORNJAČE (Chelonia mydas) TRAUMATIZOVANE U SUDARU SA MOTORNIM ČAMCEM
}

\author{
Radan Elvis Matias de OLIVEIRA, Fernanda Loffler Niemeyer ATTADEMO, \\ Augusto Carlos da Bôaviagem FREIRE, Juliana Maia de Lorena PIRES, Daniel Solon \\ Dias de FARIAS, Aline da Costa BOMFIM, Rysónely Maclay de OLIVEIRA, Simone \\ Almeida GAVILAN, Flávio José de Lima SILVA, Moacir Franco de OLIVEIRA
}

$\mathrm{U}$ ovom radu prikazane su ante- i post mortem promene nakon traume koju je zadobila zelena kornjača (Chelonia mydas), u sudaru sa motornim čamcem. Odrasla ženka zelene kornjače spašena je živa 2. decembra 2016. na plaži Ponta Negra, opština Natal, Rio Grande do Norte, Brazil. Spašena životinja poslata je u Centar za rehabilitaciju morske faune (PCCB-UERN), opština Areia Branca (RN), u Brazilu. Kliničkim pregledom utvrđena je odlična telesna kondicija, glasno disanje, umerena dehidracija, odsustvo refleksa zadnjih ekstremiteta i kloakalnih stimulacija pritiskom, te dve traumatske povrede karakteristične za sudar sa motornim čamcem. Nakon tri dana potporne terapije, životinja je uginula i odmah je poslata na obdukciju. Životinja je imala potpuni prelom tela pršljenova (dorzalni elementi D9 i D10) i presečenu kičmenu moždinu. U digestivnom traktu su pored povreda debelog creva uzrokovanih koštanim fragmentima slomljenog karapaksa bili prisutni ostaci hrane. Pluća su bila ispinjena hemoragičnim 
penastim sadržajem i sa izraženom intersticijalnom fibrozom bronhiola. Bilo je prisutno i nešto fibrina i veliki broj leukocita, mahom makrofaga. Jetra je bila uvećana, sa zaobljenim rubovima i zadebljalom kapsulom, multifokalnim područjima hepatocelularne nekroze i disocijacijom hepatocitnih traka. Sudar je rezultirao otkrivanjem celomske šupljine i kičmene moždine, što je životinji izazvalo jak bol, paralizu zadnjih ekstremiteta i kloake, septikemiju i posledično smrt. 